\title{
Kazimierz Trzęsicki
}

Higher Vocational School in Suwałki

\section{NEGATION AND INFINITY}

\begin{abstract}
Infinity and negation are in various relations and interdependencies one to another. The analysis of negation and infinity aims to better understanding them. Semantical, syntactical, and pragmatic issues will be considered.

Keywords: negation, infinity.
\end{abstract}

\section{Introduction}

From the cognitive angle, negation is distinguished by unavailability in analogical cognition (which lies at the core of human cognition), to which the mental capacities of animals are restricted, whereas in the case of infinity the acquiring of its notion by human beings is disputable.

Notions of negation as well as notions of infinity are the source of numerous paradoxes. The notion of negation alone is at the root of the liar paradox. The thesis that an infinite set is equinumerous with its proper subset is against the principle that the whole is greater than any of its proper parts (infinity in Dedekind's sense), totum maior summa partum, which has seemed to be rational. Contradictories, i.e. arguments based on negation, inspired considerations on (actual) infinity. The contradictories were used to justify the rejection of the existence of (actual) infinity, which has been affirmed in mathematics by constructivists or, as in the case of Georg Cantor, who was motivated by the question of infinity in theology, further the striving for a contradiction-free theory of infinity. As the question of conceiving of negation polarizes logicians, so the problem of the existence of infinity polarizes mathematicians.

Aristotle created the concept of potential infinity to avoid the paradoxes of the concept of actual infinity. After Cantor the negation has been modified to avoid the undesirable consequences of rejecting the concept of actual infinity. We will show that this colligation is necessary, i.e. if actual infinity is 
positively characterized, a modification of the notion of negation is necessary to reject the existence of actual infinity, and restrict it to a potential infinity. Moreover, accepting actual infinity is possible either by arranging an axiom system, the consistency of which is unprovable, or by using negation in such a way that trivializing will not take place, e.g. in naive set theory.

\section{Language representation}

\subsection{Negation}

Negation is conceived as expressing some kind of opposition. Opposites are simultaneously different and similar in meaning. In English, as well as in Polish, there are many words and many ways to express opposites; let us point to some of them:

- deny (wypierać się, dementować): He denied being involved in the affair. He denies the accusation.

- reject (odrzucać): They rejected his ideas. The theory has been rejected.

- contradict (zaprzeczać): Her way of life contradicts her stated principles. Nobody dared to contradict him. The existing layout of the city contradicted the logic of the new centre.

- refute (odpierać): His argument was refuted.

- negate (zanegować): The results of the investigation were negated.

- belie (zadawać kłam): His trembling hands belied his calm voice.

- repugn (sprzeciwiać się): Resisters of the draft in the past decade, morally repugned by an unjust war, went to jail.

- contravene (wbrew): The council held that the prosecution contravened the rights of the individual. By accepting the bribe, he was in contravention of company regulations.

- disaffirm (przeczyć): To disaffirm a contract is to say it never existed.

- negate (zaprzeczać): You can't negate facts.

- gainsay (zakwestionować): The impact of the railways cannot be gainsaid.

- rebut (odrzucić): He had to rebut charges of acting for the convenience of his political friends.

- counter (oponować): I could say the same thing about you, he countered.

- disagree (nie zgodzić się): No one was willing to disagree with him.

- repudiate (odrzucić): He has repudiated policies associated with previous party leaders.

- opposite (naprzeciwko, przeciwnie): He was sitting almost opposite. Other authors have expressed opposite views. 
To ascribe an opposite attribute some grammar devices are used:

- a: sexual - asexual

- un: imaginable - unimaginable, truth — untruth

- in: valid — invalid, finite - infinite

- im: measurable — immeasurable

- ir: rational — irrational

- less: colour - colourless

The opposite relation holds between a word and its antonym. An antonym is one of a pair of words with opposite meanings. The above lists of types of opposites are far from complete.

\subsection{Infinity}

The idea of infinity has its source in questions about the beginning and end of time, and the border of space.

In antiquity the infinite was considered as an entity with no order,

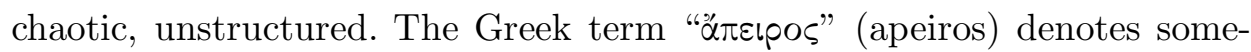
thing without a border. "Infinity" denotes also something inexhaustible. "Пદ́pas" (peras) means the same as "border", "edging", or "periphery".

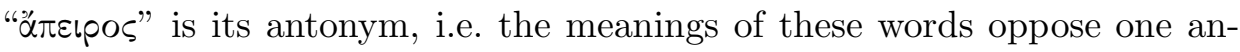

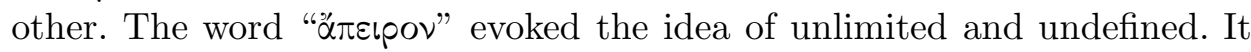
was a negative, even pejorative, word.

The language characterization of an infinite object is usually negative: infinite (nieskończony), inexhaustible (niewyczerpalny), endless (bez końca), boundless (bez granic), limitless (bez granicy), unlimited (bez ograniczeń), immeasurable (niezmierzalny), measureless (pozbawiony miary).

In the case of time the following words are used:

- negative $\div$ timeless

- positive $\div$ perpetual, eternal, sempiternal.

I do not know a word with positive meaning which denotes the infinite space.

\section{Meaning and extension}

We are interested in the underlying model-theoretic and proof-theoretic features that are specific to negation, conceived generally as a connective or an operator that forms a pair of opposite propositions or a pair of opposed predicates, respectively. The opposite meanings of propositions result in their different logical values for at least one valuation, or - in other words - at least in one model one of them is satisfied, and the other is unsatisfied. ${ }^{1}$ 
The opposite meanings of predicates result in their different extensions. Both the theses about opposite propositions and opposite predicates are assumed though they are disputable. As a counter example, Nicholas of Cusa's definition of "God" as the "coincidence of opposites" (coincidentia oppositorum) can be used, e.g. God is everywhere and nowhere; absolute and contracted; enfolding and unfolding (Nicholas of Cusa, 1985).

Let us consider expressions, propositions, or predicates, the meanings of which oppose one another. Let FORM denote a proposition or a predicate and neg be used to form an expression with the opposite meaning (a pair of propositions with opposite meanings or antonyms) - the context of the use of "FORM" and "neg" will determine their meanings. A FORM can have more FORMs with an opposite meaning. In such a case "neg" with indices could be used.

Let us distinguish, in a purely combinatorial manner, three main kinds of negation (neg). For FORM and negFORM the following situations are possible:

1. they are contrary one to the other:

- it is excluded that for some FORM and some valuation: both FORM and negFORM have designated logical value,

- extensions of FORM and negFORM are disjoint;

2. they are subcontrary one to the other:

- it is excluded that for some FORM and some valuation: both FORM and negFORM do not have a designated logical value,

- extensions of FORM and negFORM are complementary.

3. FORM and negFORM are in the relation of contradiction if and only if, for any valuation:

- exactly one of the logical values of FORM and negFORM is designated (or, in any model one and only one of FORM or negFORM is satisfied)

- extensions of FORM and negFORM are disjoint and complementary.

Such notions as "contraries", "subcontraries" and "contradictories" belong to logic in the tradition of Aristotle.

A similar division of propositional negations can be obtained on the basis of fundamental logical principles pointed out by Aristotle in Book $\Gamma$ of His Metaphysics, non-contradiction and the excluded middle. ${ }^{2}$ There are the following possibilities. The negation obeys:

- only the principle of non-contradiction,

- only the principle of the excluded middle,

- both the principles of non-contradiction and the excluded middle, 
- neither the principle of non-contradiction, nor the principle of the excluded middle.

The fourth possibility is the complete dissolution, under the name of negation, of all potency of negativity.

Intuitionistic negation is an example of negation that forms propositions which are in a contrary relation. Generally it is the case of any partial logic, i.e. such a logic which does not obey the law of the excluded middle:

for any FORM and any valuation

$$
\text { FORM or negFORM }
$$

has a designated value.

Let us add that in partial logic for some FORM and some valuation it may be the case that FORM as well as negFORM do not have any designated value.

"Friendly" and "unfriendly" can be pointed to as examples of predicates which are contrary one to the other. Their extensions are disjoint but not complementary.

Paraconsistent $\operatorname{logics}^{3}$ can be described as such which do not obey the law of non-contradiction:4

for any FORM and any valuation

\section{FORM and negFORM}

do not have designated values. Paraconsistent logics are those that allow for inconsistent but non-trivial theories.

In paraconsistent logics, the proposition FORM and its negation, negFORM, for some valuation can both have a designated value but it does not 'explode' or imply every proposition (ex contradictione sequitur quodlibet), i.e. for some FORM if for a certain valuation it is the case that FORM as well as negFORM have a designated value; it is not the case that any proposition follows from these propositions as premisses. This negative criterion unites all paraconsistent logics. Thus neg is just a subcontrariety connective and trivializing does not take place. It is also true, e.g. about the not-necessary operator (as neg) in classical logic: in the modal square of opposition FORM and negFORM are subcontrary one to the other. ${ }^{5}$

An example of a predicate such that its extension and extension of its negation are not disjoint could be attained using fuzzy set theory or the theory of rough sets.

Classical negation is an example of neg such that FORM and negFORM are contradictory one to the other. For any FORM and any valuation one of the FORM or negFORM has a designated logical value 
whereas the other one has an undesignated value. The classical negation is the proper representation of negation as it appears in classical mathematical reasoning, especially in theories for which the proof of consistency exists, e.g. Presburger arithmetic (Presburger, 1929).

In classical set theory, $A$ and its complement, $\bar{A}$, are disjoint and complementary. "Non" forms a predicate the extension of which is disjoint and complementary with the extension of its argument, e.g.: "animal" and "nonanimal".

\section{Actual and potential infinity}

The concept of infinity, though elusive and counterintuitive, plays an essential role in mathematics, the field of fundamental intellectual inquiry characterized by precision and effectiveness in modeling the real world. In theology the concept of infinity is indispensable in the characterization of the essence of God.

In order to avoid actual infinities that seemed to threaten the orderliness of his a priori finite world, Aristotle invented the notion of potential infinity.

Both notions of infinity, actual and potential, are still under discussion. Aristotle rejected the existence of actual infinity, and allowed only for potential infinity which was helpful in avoiding the most discussed ancient paradoxes of infinity.

There are two ways of considering objects: successively or simultaneously. The first one leads to the concept of number, and the second one leads to the concept of set - the human mind has the ability to recognize groups, natural or abstract. According to Aristotle, we can never conceive an infinite number of objects as a whole but some finite collections of objects are such that we can always find a larger finite collection of this kind of object, e.g. as it is in the case of any finite collection of natural numbers.

All existing objects are finite. Some of them are potentially infinite, i.e. they are finite but they could be greater in number or size than they actually are. Aristotle argued against actual infinity. In Chapters $4-8$ of Book III of Physics he wrote:

Our account does not rob the mathematicians of their science, by disproving the actual existence of the infinite in the direction of increase, in the sense of the untransversable. In point of fact they do not need the infinite and do not use it. They postulate only that the finite straight line may be produced as far as they wish. 
Aristotle's conception of infinity impacted on Euclid, the "father of geometry", famous for his epochal invention of a deductive axiom system and his Elements - one of the most influential works in the history of mathematics. In the 19th century Friedrich Gauss, the prince of mathematicians, defended Aristotles' way of conceiving of infinity in mathematics. In a letter to Schumacher in 1831 he wrote (Peters, 1860-1865, Brief Nr. 396 von Gauss an Schumacher am 12.7.1831, http://www.sgipt.org/wisms/geswis/mathe/ gsb396.htm):

...so protestire ich zuvörderst gegen den Gebrauch einer unendlichen Grösse als einer Vollendeten, welcher in der Mathematik niemals erlaubt ist. Das Unendliche ist nur eine Façon de parler, indem man eigentlich von Grenzen spricht, denen gewisse Verhältnisse so nahe kommen als man will, während anderen ohne Einschränkung zu wachsen verstattet ist.

...I protest against the use of infinite magnitude as something completed, which in mathematics is never permissible. Infinity is merely a façon de parler, the real meaning being a limit which certain ratios approach indefinitely near, while others are permitted to increase without restriction.

For Aristotle (Aristotle, 1961, III.7.208a, p. 56):

...being infinite is a privation, not a perfection but the absence of a limit.

The idea of actual infinity as something irrational is a problem of theology. The Christian idea of an infinite and rational God was a challenge to philosophers and theologians. St. Thomas Aquinas accepted Aristotle's attitude towards actual infinity in order to be able to talk about an infinite (rational) God, its "irrationality" limited to quantity or to what is finite according to place. Neither an actually infinite multitude nor an actually infinite magnitude is possible. But there is no quantity in God and He is not a body. According to Thomas:

...omnes antiqui philosophi attribuunt infinitum primo principio, ut dicitur in III Physic., et hoc rationabiliter, considerantes res effluere a primo principio in infinitum. Sed quia quidam erraverunt circa naturam primi principii, consequens fuit ut errarent circa infinitatem ipsius. Quia enim ponebant primum principium materiam, consequenter attribuerunt primo principio infinitatem materialem; dicentes aliquod corpus infinitum esse primum principium rerum.

All the ancient philosophers attribute infinitude to the first principle, as is said (Phys. iii), and with reason; for they considered that things flow forth infinitely from the first principle. But because some erred concerning the nature of the first principle, as a consequence they erred also concerning its 
infinity; forasmuch as they asserted that matter was the first principle; consequently they attributed to the first principle a material infinity to the effect that some infinite body was the first principle of things. (Thomas Aquinas, 1947, I a, q.7 a.1)

The question of the infinitude of God is solved by Thomas by introducing the concept of infinity in essence:

Forma autem non perficitur per materiam, sed magis per eam eius amplitudo contrahitur, unde infinitum secundum quod se tenet ex parte formae non determinatae per materiam, habet rationem perfecti. Illud autem quod est maxime formale omnium, est ipsum esse, ut ex superioribus patet. Cum igitur esse divinum non sit esse receptum in aliquo, sed ipse sit suum esse subsistens, ut supra ostensum est; manifestum est quod ipse Deus sit infinitus et perfectus.

On the other hand, form is not made perfect by matter, but rather is contracted by matter; and hence the infinite, regarded on the part of the form not determined by matter, has the nature of something perfect. Now being is the most formal of all things, as appears from what is shown above (Question [4], Article [1], Objection [3]). Since therefore the divine being is not a being received in anything, but $\mathrm{He}$ is His own subsistent being as was shown above (Question [3], Article [4]), it is clear that God Himself is infinite and perfect. (Thomas Aquinas, 1920, First Part, Question 7, Article 1)

For Nicolas of Cusa, God is the absolute Maximum, i.e. Maximum free from any limits, is unlimited. "Absolute" in its etymological sense means "free-from" (ab-solutus).

Dedekind provided, for the first time in history, a definition involving the infinite (as multitude or magnitude ${ }^{6}$ ) in positive terms (i.e. not in negative terms such as in-finite or non-finite). He said (using modern terminology) that a set $S$ is infinite if and only if there exists a proper subset $S^{\prime}$ of $S$ such that the elements of $S^{\prime}$ can be put into one-to-one correspondence with those of $S$. Only infinite sets have this property (Núñez, 2017).

Cantor, over two thousand years after Aristotle, argued that the distinction between potential and actual infinities is dubious (Cantor, 1932, p. 404):

...während doch in Wahrheit das P.-U. [P.-U.: Potential Infinity] nur eine geborgete Realität hat, indem es stets auf ein A.-U. [A.-U.: Actual Infnity] hinweist, durch welches es erst möglich wird.

...in truth the potentially infinite has only a borrowed reality, insofar as a potentially infinite concept always points towards a logically prior actually infinite concept whose existence it depends on. 
The contemporary mathematical concept of infinity is the almost singlehanded creation of Georg Cantor. He distinguishes between the Absolute Infinite, the physical infinities, and mathematical infinities (Cantor, 1932, p. 378):

Es wurde das A.-U. [A.-U.: Actual Infnity] nach drei Beziehungen unterschieden: erstens sofern es in der höchsten Vollkommenheit, im völlig unabhängigen, außweltlichen Sein, in Deo realisiert ist, wo ich es Absolutunendliches oder Kurzweg Absolutes nenne; zweitens sofern es in der abhängigen, kreatürlichen Welt vertreten ist; drittens sofern es als mathematische Größ, Zahl order Ordnungstypus vom Denken in abstracto aufgefaßt werden kann. In den beiden letzten Beziehungen, wo es offenbar als beschränktes, noch wieter Vermehrung fähiges und insofern den Endlichen verwandts A.U. sich darstellt, nenne ich es Transfinitum und setze es den Absoluten strengsten engegen.

The actual infinite arises in three contexts: first when it is realized in the most complete form, in a fully independent other-worldly being, in Deo, where I call it the Absolute Infinite or simply Absolute; second when it occurs in the contingent, created world; third when the mind grasps it in abstracto as a mathematical magnitude, number, or order type. I wish to make a sharp contrast between the Absolute and what I call the Transfinite, that is, the actual infinities of the last two sorts, which are clearly limited, subject to further increase, and thus related to the finite. (Rucker, 2013, p. 13), (Russell, 2011, p. 282)

Cantor's solution had enormous impact on the development of mathematics. He was perhaps the first scholar who really understood the meaning of infinity and gave it mathematical precision. The notion of actual infinity is rich and powerful. Without it most of mathematics would simply disappear. Its role is expressed with Hilbert's famous saying (1928b, p. 170):

Aus dem Paradies, das Cantor uns geschaffen, soll uns niemand vertreiben können.

From the paradise that Cantor created for us, no-one can expel us.

Concluding the above considerations we maintain that:

1. actual infinity exists in a primary sense but the existence of potential infinity is towards it secondary, derivative,

2. the notion of actual infinity is positive whereas the notion of potential infinity is negative, i.e. negation is essential for its characterization,

3. the notion of actual infinity plays an important role in mathematics, the most precise human intellectual activity. 


\section{Concepts of infinity and properties of negation}

Russell's paradox of the set of all sets that are not elements of itself showed that Cantor's concept of set could not be free from contradictions. Other inconsistencies were found: 1908 - Burali-Forti's paradox of the "set of all ordinals", 1909 - Mirimanoff's paradox of the "set of all sets not containing an infinite descending element sequence", etc. Axiomatic theories were designed to substitute Naïve Mengenlehre and to avoid contradictions.

Hilbert's program to find a complete and consistent set of axioms for all mathematics turned out to be not accomplishable. Gödel proved that in any first-order axiomatic theory, any formal system that is of sufficient complexity to express the basic arithmetic of the natural numbers, cannot demonstrate (using finitistic rules of inference, or - in modern language a computer program) its own consistency. ${ }^{7}$ Many not intuitive theorems, e.g. some consequences of the axiom of choice, may yield queries about the consistency of axiomatic set theory. The fact that for over 100 years we did not experience a contradiction in a formal system of set theory is the only reason to believe in the consistency of the system. The language of Cantorian set theory is the lingua franca of contemporary classical mathematics; every mathematical object can be represented by a set, and for this reason a presumptive contradiction will be only an opportunity to improve and not to reject the system of set theory. Axiomatic systems are prevented from contradiction by the choice of axioms and rules of (formal) inference.

The paraconsistent negation can be an additional operator in the language with a classical negation. The paraconsistent logic of the language will be an extension of classical logic. Thus it would be rather an extension than a rejection of classical rationality (Granger, 1998; Béziau, 2002).

Mathematicians usually work with the Naïve Mengenlehre, adding that in any case it will be possible to base any proof on an axiom system of set theory. But Bourbaki ${ }^{8}$ has in any case always ignored axiomatic set theory, and he is still working with the Naïve Mengenlehre, which he uses contentedly without generating any contradictions (Mathias, 1992). The logic of the language of Bourbaki's mathematics can be described as (potentially) paraconsistent. The negation of the language is used in its subcontrary sense without trivializing, i.e. without having any proposition as a theorem: we know that in the Naïve Mengenlehre some contradictions can be proved but we avoid their use of negation according to the (not necessarily formal) rules of paraconsistent logic, in which the explosion axiom "contradiction implies everything" is refused. The same would be true about Cusa's theology: not all sentences are theorems despite that some theo- 
rems of Cusa's theology oppose one another, or despite the fact that one is a (paraconsistent) negation of the other.

The language of legal systems can be considered as containing classical as well as paraconsistent negations. There are two kinds of legal argumentation. Besides the rules of classical logic there are rules, which are usually called "the rules of legal reasoning". Paraconsistent negation does not result in exploding due to the rules of legal reasoning. Any of the rules, rationally used, prevents legal reasoning from evident and unremovable inconsistencies of conclusions. There are five groups of legal reasonings (Malec, 2001):

1. rules of interpretation, used to reconstruct the meaning of legal expressions; e.g. clara non sunt interpretanda,

2. rules of inference, used to infer consequences from legal norms; e.g. per analogiam (a simili), a contrario, a fortiori (a maiori ad minus, a minori ad maius),

3. rules of collision, used to solve collisions of legal norms; e.g. lex posterior derogat legi priori,

4. the rules used to determine factual circumstances; e.g. in dubio pro reo (in dubio pro libertate),

5. the rules of procedure; e.g. a judge should consider arguments of both parties.

Aristotle created the concept of potential infinity to resolve paradoxes of actual infinity. Intuitionists and constructivists do not accept Cantorian set theory and reject the concept of actual infinity as a mathematical concept. Many solutions of the problem of establishing mathematics without the concept of actual infinity have been undertaken. Brouwer initiated an intuitionistic philosophy of mathematics. Intuitionistic logic, sometimes more generally called constructive logic, is one of a set of approaches to constructivism in mathematics. Constructive logic refers to systems of symbolic logic that differ from the systems used for classical logic by more closely mirroring the notion of constructive proof.

Leopold Kronecker - famous for his saying that "Die ganzen Zahlen hat der liebe Gott gemacht, alles andere ist Menschenwerk"9 (God created the integers, all else is the work of man) - one of the most hard-fought of Cantor's opponents, is an inceptor of the constructive approach to mathematical proofs. He was skeptical of the notion of infinity and believed that mathematics should deal only with finite numbers and with a finite number of operations. In consequence he opposed the use of irrational numbers. Kronecker complimented Lindemann on his proof that $\pi$ is transcendental but, he claimed, transcendental numbers do not exist. ${ }^{10}$ Kronecker maintained that there are no irrational numbers in the physical world. His skepticism 
was developed in the philosophy of mathematics called finitism, an extreme form of the philosophical and mathematical schools of constructivism and intuitionism.

Let us remark that theories which accept actual infinity use negation in a classical or paraconsistent meaning; in particular the law of the excluded middle, $\phi \vee \neg \phi$, and double negation elimination, $\neg \neg \phi \rightarrow \phi$, are approved. In classical logic premises $\phi$ and $\neg \phi$ are sufficient to prove any proposition. In paraconsistent logic it does not hold. In theories in which the existence of actual infinity is rejected, the fundamental laws of classical negation are in various ways restricted. First of all this concerns the law of the excluded middle.

In Hilbert-style calculus the intuitionistic negation is defined as: $\perp \rightarrow \phi$. Systems of intuitionistic logic do not include (as universally valid) the law of the excluded middle and double negation elimination, which are fundamental inference rules in classical logic. The law of the excluded middle and double negation elimination can still be proved for some propositions on a case by case basis. In the case of Brouwer-Heyting-Kolmogorov-interpretation, if FORM is proved or if is proved its negation, then for this FORM it is true that FORM or negFORM. Intuitionist existence proofs are mostly very complicated and plagued by unpleasant exceptions.

The system of intuitionistic logic, which formalizes Brouwer's original semantic intuitions, was originally developed by Arend Heyting (Heyting, 1930, 1956). In the Heyting system of intuitionistic logic there is no characteristic matrix with a finite numbers of values, i.e. such a matrix which verifies all theorems and falsifies all non-theorems of Heyting's system (Gödel, 1986; Jaśkowski, 1936). Operations in intuitionistic logic preserve justification, with respect to evidence and provability, rather than to truth-valuation. Heyting's intuitionistic logic includes the principle that contradictions imply everything.

The rejection of the law of the excluded middle was strongly criticized by Hilbert (Hilbert, 1928a, vol. VI, p. 80):

Dieses Tertium non datur dem Mathematiker zu nehmen, wäre etwa, wie wenn man dem Astronomen das Fernrohr oder dem Boxer den Gebrauch der Fäuste untersagen wollte. Das Verbot der Existenzsätze und des Tertium non datur kommt ungefähr dem Verzicht auf die mathematische Wissenschaft überhaupt gleich.

Taking the principle of the excluded middle from the mathematician would be the same, say, as proscribing the telescope to the astronomer or to the boxer the use of his fists. To prohibit existence statements and the principle of the excluded middle is tantamount to relinquishing the science of mathematics altogether. 
The defence of the principle of the excluded middle here becomes not merely polemical, but even seems exaggerated.

Let us distinguish two kinds of proof.

Proof of negation - the same classically and intuitionistically - is an inference rule which explains how to prove a negation:

- To prove $\neg \phi$, assume $\phi$ and derive the absurdity.

Proof by contradiction, reductio ad absurdum, is a reasoning principle:

- To prove $\phi$, assume $\neg \phi$ and derive absurdity.

The proof of negation, as based on the law of introduction of double negation, is allowed, but proof by contradiction, as based on the law of elimination of double negation, is not allowed in intuitionistic logic

Some semantics of Brouwer's idea of logic persistently induce logics properly stronger than Heyting's logic. Some authors have argued that this might be an indication of the inadequacy of Heyting's calculus itself, deeming the latter incomplete as a constructive logic (Japaridze, 2009).

The concept of constructive negation as reduction to absurdity can be considered also from the paraconsistent point of view (Odintsev, 2008).

\section{Conclusions}

The thesis that in any case of using the concept of infinity, independently of whether actual or potential, there are problems with negation conceived as an operation of forming opposite propositions or predicates, should be the subject of deeper analysis.

Theories of (actually) infinite domains cannot demonstrate their own consistency, if classical negation is used in the language of these theories. This means that in the practical development of the theories, inconsistency is prevented either by an axiom system or by avoiding reasoning which leads to trivializing, i.e. when negation is used in its paraconsistent mode.

In theology there is the problem of positive knowledge about an infinite God. Some theologians prefer apophatic theology, i.e. they maintain that our knowledge of God can be expressed only in negative terms. Via negations is a "way" for proving the existence of God and knowing Him: it results in verbal declarations of "what God is not". The cataphatic theology purports the possibility of positive statements about God. As we remarked at the beginning of these considerations, negative cognition does not base on analogy. If we do not experience any infinite object, we are not able to achieve 
using analogy any positive knowledge about any infinite object. We may ask if the negative logic of the language of apophatic theology, as a counterpart of positive logic, prevents apophatic theology from inconsistencies and then how negation is understood within it.

Theories of potentially infinite domains have to use negation in its constructive meaning. It is interesting which of the possible constructive meanings of constructive negation have to be favoured, if any.

Classical negation is used in the languages of theories of finite domains. Non-classical negation is used in a language which is free from the concept of infinity, as it is in the case of legal reasoning in which paraconsistent negation is used, and in the case of constructive negation, which is included in logic programs - full logic negation tends to the super-exponential time complexity of provers. The reasons for accepting constructive negation are the preservation of the advantages of negation as failure.

\section{$\mathrm{N} \mathrm{O} \mathrm{T} \mathrm{E} \mathrm{S}$}

1 Three kinds of negation can be distinguished according to the representability of logics. A negation is (Béziau, 2002):

- truth-functional iff it is characterized by a finite-matrix,

- Leibnizian iff it is constructed by a possible world semantics,

- effective iff it is characterized with a recursive proof-system, etc.

In what follows we will restrict the description of negation characterized truth-functionally or, in the case of predicates, characterized by extension. Some modifications of this description will be sufficient also for describing other kinds of negation.

${ }^{2}$ When Greece started to use the principle of non-contradiction more than two thousands years ago, it was the start of mathematics and science in general (Szabó, 1978).

3 Stanisław Jaśkowski was one of the first to propose a formal calculus of inconsistencytolerant, or paraconsistent logic (Jaśkowski, 1949, 1948).

${ }^{4}$ Rejection of the law of non-contradiction does not necessarily result in the rejection of rationality. Heraclitus and Hegel defended a kind of rationality not based on this, even based on something which appears as the contrary of it.

${ }^{5}$ For more on paraconsistent negation see (Carnielli \& Coniglio, 2016; Béziau, 2002).

${ }^{6}$ Let us remark that ancient Greeks did not consider geometric magnitudes to be numbers at all.

7 Our knowledge of infinite mathematical domains remains - which Gödel's theorems on undecidability and incompleteness (Gödel, 1931, 1934) imply - potentially infinite. The same is true about our knowledge of God. Only the infinite mind is able to acquire infinite knowledge. The consistency of the first-order Peano axioms is provable with the principle of quantifier-free transfinite induction up to the ordinal $\epsilon_{0}$. (Gentzen, 1936, 1938)

8 Nicholas Bourbaki - a group of mainly French 20th-century mathematicians aimed to reformulate mathematics and ground it on set theory.

${ }^{9}$ Quoted by Weber (1893, p. 19). Kronecker told it in a lecture for Berliner Naturforscher-Versammlung in 1886. 
10 The representation of real numbers by actually infinite sets is the only way to get their mathematical representation. Dedekind's definition of real numbers as a pair of infinite sets is taken over almost unaltered from Eudoxian theory of proportion given in Euclid's Elements, Book V. The difference between what Eudoxus and Dedekind did is that Eudoxus thought of the ratio with the description in terms of potentially infinite infinite sets (Rucker, 2016).

\section{R E F E R E N C E S}

Aristotle. (1961). Physics. Lincoln: University of Nebraska Press. (Richard Hope, trans.)

Béziau, J.-Y. (2002). Are paraconsistent negations negations? In W. A. Carnielli, M. E. Coniglio, \& I. M. Loffredo D'Ottaviano (Eds.), Paraconsistency: the logical way to the inconsistent (pp. 465-486). New-York: Marcel Dekker. Retrieved from www.jyb-logic.org/papers12-11/paraconsistent\%20negations.pdf

Cantor, G. (1932). Gesammelte Abhandlungen mathematischen und philosophischen Inhalts. Mit Erläuterunden Anmerkungen sowie mit Ergänzungen aus den Briewechsel Cantor-Dedekind. Nebst einem Lebenslauf Cantors von A. Fraenkel (E. Zermelo, Ed.). Berlin, Göttingen: Verlag von Julius Springer. Retrieved from http://gdz.sub.uni-goettingen.de/dms/load/pdf/?PPN=PP N237853094\&DMDID=DMDLOG_0059\&LOGID=LOG_0059\&PHYSID=P HYS_0391 (Reprinted: Hildesheim 1962; 2nd ed. Springer, Berlin 1980 Mit erläuternden Anmerkungen sowie mit Ergänzungen aus dem Briefwechsel Cantor-Dedekind; reprint 2013. Available online)

Carnielli,W., \& Coniglio, M. E. (2016). Paraconsistent logic: Consistency, contradiction and negation (Vol. 40). Springer International Publishing.

Davis, M. (Ed.). (1965). The undecidable: Basic papers on undecidable propositions, unsolvable problems, and computable functions (1965, 2004 ed.). Hewlett, N.Y.: Raven Press. (An anthology of fundamental papers on undecidability and unsolvability, this classic reference opens with Gödel's landmark 1931 paper demonstrating that systems of logic cannot admit proofs of all true assertions of arithmetic. Subsequent papers by Gödel, Church, Turing, and Post single out the class of recursive functions as computable by finite algorithms. 1965 edition.)

Gentzen, G. (1936). Die Widerspruchsfreicheit der reinen Zahlentheorie. Mathematische Annalen, 112, 493-565. (Translated as The consistency of arithmetic, in $(?, ?)$.)

Gentzen, G. (1938). Neue Fassung des Widerspruchsfreicheitsbeweises für die reine Zahlentheorie. Forschungen zur Logik und Grundlegung der exakten Wissenschaften, 4, 19-44. (Translated as New version of the consistency proof for elementary number theory, in (?, ?).)

Gentzen, G. (1969). The collected papers of Gerhard Gentzen (M. E. Szabo, Ed.). Amsterdam: North-Holland. 
Gerardy, T. (1969). Nachträge zum Briefwechsel zwischen Carl Friedrich Gauss und Heinrich Christian Schumacher. Göttingen: Vandenhoeck u. Ruprecht.

Gödel, K. (1931). Über formal unentscheidbare Sätze der Principia Mathematica und verwandter Systeme I. Monatshefte für Mathematik und Physik, 38, 173-198. (Received: 17.XI.1930. Translated in: (?, ?, 144-195). Includes the German text and parallel English translation. English translations in (?, ?, 5-38), (?, ?, 595-616). Online version (translation by B. Meltzer, 1962): http://www.ddc.net/ygg/etext/godel/, PDF version (translation by M. Hirzel): http://nago.cs.colorado.edu/ hirzel/papers/canon00-goedel.pdf)

Gödel, K. (1934). On undecidable propositions of formal mathematical systems. ((mimeographed lecture notes, taken by S. C. Kleene and J. B. Rosser at the Institute for Advanced Study), Princeton; Reprinted in: (?, ?, 39-74))

Gödel, K. (1986a). Collected works (Vols. 1 Publications 1929-1936; S. Feferman, J. Dawson, \& S. Kleene, Eds.). New York: Oxford University Press.

Gödel, K. (1986b). Collected works. Publications 1929-1936 (Vol. 1; S. Feferman, J. W. Dawson Jr., S. C. Kleene, G. H. Moore, R. M. Solovay, \& J. van Heijenoort, Eds.). Oxford University Press Inc, USA.

Granger, G. G. (1998). L'irrationnel. Paris: Odile Jacob.

Heyting, A. (1930). Die formalen Regeln der intuitionistischen Logik. Sitzungsberichte der preußischen Akademie der Wissenschaften, phys.-math. Klasse, $42-56$.

Heyting, A. (1956). Intuitionism. an introduction (1st ed.). Amsterdam: NorthHolland Publishing Co. (2nd edition 1966)

Hilbert, D. (1928a). Die Grundlagen der Mathematik. Abhandlungen aus dem Seminar der Hamburgischen Universität, 6, 65-85. (followed by Diskussionsbemerkungen zu dem zweiten Hilbertschen Vortrag by H. Weyl, pp. 86-88, and Zusatz zu Hilberts Vortrag by P. Bernays, pp. 89-95; shortened version in (?, ?), 7th ed., pp. 289-312; English translation (by S. Bauer-Mengelberg and D. Follesdal) in (?, ?), pp. 464-479. On-line publication www.marxists. org/reference/subject/philosophy/works/ge/hilbert.htm)

Hilbert, D. (1928b). Über das Unendliche. Mathematische Annalen, 95, 161-190. Retrieved from http://eudml.org/doc/159124 (Lecture given in Münster, 4 June 1925)

Hilbert, D. (1998). The theory of algebraic number fields. Berlin: Springer Verlag.

Jaśkowski, S. (1936). Recherches sur le systéme de la logique intuitioniste. In Actes du Congrés International de Philosophie Scientifique (Vol. 6, pp. 58-61). Paris.

Jaśkowski, S. (1948). Rachunek zdań dla systemów dedukcyjnych sprzecznych. Studia Societatis Scientiarun Torunesis, 1(5), 55-77. (An English translation: $(?, ?))$

Jaśkowski, S. (1949). O koniunkcji dyskusyjnej w rachunku zdań dla systemów dedukcyjnych sprzecznych. Studia Societatis Scientiarum Torunensis (Sectio A), 1(8), 171-172. (An English translation appeared as (?, ?)) 
Jaśkowski, S. (1969). A propositional calculus for inconsistent deductive systems. Studia Logica, 24, 143-157. (An English translation of (Jaśkowski, 1948) (reprinted in (?, ?)))

Jaśkowski, S. (1999). On the discussive conjunction in the propositional calculus for inconsistent deductive systems. Logic and Logical Philosophy, 7, 57-59. (An English translation of (Jaśkowski, 1949))

Japaridze, G. (2009). In the beginning was game semantics? In O. Majer, A. Pietarinen, \& T. Tulenheimo (Eds.), Games: Unifying logic, language, and philosophy (Vol. 15, pp. 249-350). Springer Netherlands. Retrieved from https:// www.researchgate.net/.../259202450_In_the_Beginning_was_Game_Semantics

Malec, A. (2001). Legal reasoning and logic. Studies in Logic, Grammar and Rethoric, 4(17), 97-101.

Mathias, A. R. D. (1992). The ignorance of Bourbaki. The Mathematical Intelligencer, 14(3), 4-13. Retrieved from https://www.reddit.com/r/math/comm ents/24f8mp/the_ignorance_of_bourbaki_pdf/

Nicholas of Cusa. (1985). On learned ignorance (de docta ignorantia) (2nd ed., Vol. 1; P. Wilpert, Ed.). Minneapolis, Minnesota: The Arthur J. Banning Press. Retrieved from www1.umn.edu/ships/galileo/library/cusa2.pdf (The translation of Book I was made from De docta ignorantia. Die belehrte Unwissenheit, Book I (Hamburg: Felix Meiner, 1970, 2nd edition), text edited by Paul Wilpert, revised by Hans G. Senger.)

Núũez, R. E. (2017). Conceptual metaphor and the cognitive foundations of mathematics: Actual infinity and human imagination. Retrieved from www.cog sci.ucsd.edu/ nunez/web/SingaporeF.pdf

Odintsev, S. (2008). Constructive negations and paraconsistency (Vol. 26). Springer Netherlands.

Peters, C. A. F. (Ed.). (1860-1865). Briefwechsel zwischen C. F. Gauß und H. C. Schumacher. Altona-Esch. (Nachdruck Hildesheim: Olms 1975 in drei Bänden I, II, III, wovon jeder Band des Nachdrucks 2 Bde. der Peters-AltonaEsch-Ausgabe enthält. Bd. 1 (1860): Briefe 1808-1825. Bd. 2: 1824/2502/1836. Bd. 3 (1861): 03/1836-12/1840. Bd. 4 (1862): 01/1841-04/1845. Bd. 5 (1863): 05/1845-09/1848. Bd. 6 (1865): 12/1848-11/1850. Trotz den Volumens ist der Briefwechsel nicht vollständig: (?, ?). Zum Inhalt der Briefe: http://www.math.uni-hamburg.de/math/ign/gauss/register.htm)

Presburger, M. (1929). Über die Vollständigkeit eines gewissen Systems der Arithmetik ganze Zahlem, in welchem die Addition als einzige Operation hervortritt. In Comptes Rendus du I Congrés de Mathématiciens des Pays Slaves (pp. 92-101). Warsaw.

Rucker, R. (2013). Infinity and the mind: The science and philosophy of the infinite. Princeton University Press. Retrieved from http://www.rudyrucker.com/ infinityandthemind/\#calibre_link-354 
Russell, R. J. (2011). God and infinity: Theological insights from Cantor's mathematics. In M. Heller \& W. H. Woodin (Eds.), Infinity. New research frontiers (pp. 275-289). Cambridge: Cambridge University Press.

Szabó, A. (1978). The beginnings of greek mathematics. Dordrecht: D. Reidel.

Thomas Aquinas. (1920). Summa theologica. Online Edition Copyright (c) 2008 by Kevin Knight. Retrieved from http://www.newadvent.org/summa/index. html (Second and Revised Edition. Literally translated by Fathers of the English Dominican Province)

Thomas Aquinas. (1947). Summa theologica. Benziger Bros. Retrieved from http://dhspriory.org/thomas/summa/FP.html (Translated by Fathers of the English Dominican Province)

van Heijenoort, J. (Ed.). (1967). From Frege to Gödel. A source book in mathematical logic 1879-1931 (1st ed.). Cambridge Mass.: Harvard University Press. (2nd ed., 1971, 3rd ed. 1976)

Weber, H. (1893). Leopold Kronecker. Jahresbericht der Deutschen MathematikerVereinigung, 2, 5-31. Retrieved from http://www.digizeitschriften.de/dms/ resolveppn/?PPN=PPN37721857X_0002 